\title{
Особливості становлення провідних напрямків дослідження в українській психології середини XX століття у одеському та харківському наукових осередках
}

\begin{abstract}
Анотація. У статті проаналізовані психологічні дослідження в Украӥні, щзо відбувалися на основі експериментальних даних та ідей провідних наукових лідерів, які впроваджували свої теоретико-методологічні положення з допомогою своїх друзів та соратників. Таким чином, утворювалися творчі групи, щзо спільно працювали та підтримували один одного в наукових дослідженнях. Найбільш відомими, окрім київської групи, стали творчі колективи, щуо утворилися в Харкові та Одесі. Їх основні дослідження висвітлювали такі теми: проблеми мимовільної та довільної пам'яті, особливості продуктивного запам'ятовування, експериментальне вивчення процесу мислення, дослідження сприймання часу.
\end{abstract}

Ключові слова: украӥнська психологія, свідомість, пам'ять, сприймання часу.

Постановка проблеми. Сучасний piвень розвитку психології вимагає збагачення досліджень науковими надбаннями попередніх поколінь. Зняття ідеологічних протиріч допомагає зрозуміти сутність психологічних знань.

Аналіз останніх досліджень 3 проблеми. Розвиток української психологічної науки відбувався у складних соціальних умовах, коли наука була заручницею як політичних, так і економічних чинників. Української держави, як політичного інституту, не існувало, і тому не було єдиного суспільного центру, який би виступав джерелом розвитку психології в Україні. Тому психологічна наука розвивалася у декількох центрах, де кожний об'єднував плеяду вчених, які спеціалізувалися на вивченні певних напрямків психологічних проблем. Так, зокрема, яскраво виділився одеський напрямок, що дав початок психофізіологічним (I. М. Сєченов), експериментально-психологічним (М.М. Ланге) i теоретико-методологічним дослідженням (С. Л. Рубінштейн).

Серед вчених, що займалися вивченням української психології в середини ХХ століття у східних та південних регіонах необхідно відмітити внески: I. М. Пивоварчик, О. С. Соколової, Г.К. Середи, Л.Н. Указної, О. Ясницького та ін. В той же час дослідження проблем історії розвитку психоло- гії продовжуються в працях Л.Н. Акимової, .В.Галустової, П. П. Криворучка, О. С. Лучиніна, І. П. Манохи, В.М. Мартинюк, Т. Д. Марцинковської, та ін.

Мета даної роботи: полягає у дослідженні психологічних парадигм наукових напрямків із витоками у певних українських інтелектуальних центрах.

Виклад основного матеріалу дослідження. Харківський напрямок ознаменував собою дослідження таких психологічних феноменів: О.М. Леонтьєв - теорії діяльності, О. В. Запорожець - теорії сприйняття, П. І. Зінченко - теорії пам'яті, П. Я. Гальперин - теорії поетапного формування розумових дій, Л.І. Божович - теорії особистості.

На початку 30-х років Л.С. Виготському, О.Р. Лурія й О.М. Леонтьєву запропонували організувати відділення психології в психоневрологічній академії в Харкові. У Харкові О.М. Леонтьєву довелося одночасно очолювати кафедру психології в педінституті і відділ психології в НДІ педагогіки. Разом 3 ними 3 Москви в Харків переїхали О.В. Запорожець i Л. І. Божович. Л.І. Божович через деякий час виїхала до Полтави, де вона й проживала, а в Харків приїжджала працювати. Л.С. Виготський заочно учився в Харківському медичному інституті та періодично приїжджав у Харків, залишаючись спів- 
працювати у відділенні психології в психоневрологічній академії. В тому ж самому відділенні, який очолював О. М. Леонтьєв, працював і П.Я. Гальперин, харківський психоневролог і психолог. До них приєдналася ще одна група психологів, що вийшла 3 аспірантури Харківського педагогічного інституту й Українського науково-дослідного інституту педагогіки, до якої входили В.І. Аснін, П. І. Зінченко, Г. Д. Цибуль. Вищеназвані вчені заклали теоретичний i експериментальний фундамент теорії діяльності [8; 14].

Окрім названих психологів, у 30-ті роки до цієї групи увійшли також Д. М. Арановська, Ф. В.Бассин, Е. В. Гордон, О. М. Кінцева, Л. І. Котлярова, Г. В. Мазуренко, В. В. Мистюк, Т. І. Титаренко, К.Е. Хоменко. В 1934 році О.М. Леонтьєв повернувся до Москви, але він постійно бував у Харкові і керував роботою своєї групи. П.Я. Гальперин, О. В. Запорожець, П. І. Зінченко залишалися в Харкові до початку Великої Вітчизняної війни. Після війни ні П.Я. Гальперин, ні О.В. Запорожець у Харків уже не повернулися. У зв'язку з історичними подіями, коли у 1936 році столиця України перемістилася до Києва, психологічні дослідження, що проводилися на базі Всеукраїнської психоневрологічної академії, почали згортатися. ІІї наукові надбання продовжувалися в Українському науково-дослідному інституті педагогіки, Харківському педагогічному інституті, у якому кафедрою психології завідував О.В. Запорожець і працювали В. І. Аснін, К.Е. Хоменко, Г.Д. Цибуль та ін., а також в Харківському інституті іноземних мов, у якому працював П. І. Зінченко. Він став неформальним лідером харківської групи психологів, розкиданих по різних наукових установах і інститутах міста, він же очолив психологічну лабораторію - філію київського інституту психології. Таким чином, харківська група збереглася, продуктивно працювала, публікувала десятки статей у «Наукових записках» харківських інститутів, київського інституту психології, потім у «Радянській педагогіці», а з 1955 р. - у «Питаннях психології» [8; 9; 14].
Після війни сфери наукових інтересів цих дослідників розділилися, практично кожний 3 них займався власною проблематикою і став засновником свого напрямку в психології: О.М. Леонтьєв - теорії діяльності, О.В. Запорожець - теорії сприйняття, П.І. Зінченко - теорії пам'яті, П. Я. Гальперин — теорії поетапного формування розумових дій, Л.І. Божович теорії особистості. Однак усі ці напрямки мали загальну наукову основу — теорію діяльності, що розроблялася спільними зусиллями. О.М. Леонтьєв був лідером харківської групи, однак її концепція створювалася колективно, й усі вони вважали себе учнями Л.С. Виготського.

У своїх роботах П. І. Зінченко, займаючись проблемами мимовільного та довільного запам'ятовування, стверджував, що найбільш продуктивно запам'ятовувався матеріал тоді, коли він входив у зміст цілі дії. Саме у цих випадках складалися найбільш сприятливі умови для утворення та закріплення нервових зв'язків у мозку: місце цілі дій, займане матеріалом, забезпечувало активну та змістовну орієнтацію у ньому, а досягнення мети, результату дії забезпечувало найбільш ефективне його підкріплення. $€$ підстави вважати, що встановлена психологічна залежність мимовільного запам'ятовування від цілей, задач діяльності $є$ основною, визначальною. В ній знаходить своє пояснення і ряд других закономірностей, що характеризують залежність мимовільного запам'ятовування від способів мотивів діяльності. [3, с. 264]

Основні положення грунтувалися на діяльнісному підході та виявляли залежність продуктивності мимовільного запам'ятовування від його змістовної сторони, способів діяльності. Чим більше змістовні зв'язки розкривалися у матеріалі завдяки тому чи іншому способу дії тим продуктивнішим виявлялося мимовільне запам'ятовування. Велика розумова активність сприяла перетворенню цих способів на самостійні цілеспрямовані дії. Змістовні способи діяльності виявлялися більш продуктивними не тільки тому, що давали 
можливість відкривати у матеріалі глибший змістовний зміст, але і тому, що вони вимагали від людини розумової активності. Факт детермінації розумової активності був безсумнівним та дуже важливим у характеристиці як природи мимовільного запам'ятовування, так і умов його продуктивності [3, с. 276].

Чим змістовніший спосіб діяльності, тим він складніший по тому складу окремих операцій, 3 яких складається. Саме завдяки більшій складності він вимагає від піддослідного більшої розумової активності у своєму здійсненні. Понятійні зв'язки між словами є більш змістовними, аніж конкретні. Вони є складнішими, тож встановлення цих зв'язків вимагає більшої розумової активності.

Мимовільне запам'ятовування було продуктом всієї сукупності особливостей тієї діяльності, в якій воно здійснювалося. Більша чи менша активність суб'єкта, зумовлена більшою чи меншою складністю діяльності, безсумнівно впливала на характер процесу іiі функціонування.

Є привід вважати, що чим складнішими були способи діяльності, тим сприятливіші умови створювалися для переходу певного способу діяльності у відносно самостійну цілеспрямовану дію. У зв'язку 3 таким переходом змінювалася докорінним чином структура і характер функціонування самої діяльності; змінювалося і місце, зайняте певним матеріалом у діяльності.

Простий спосіб дій, що не вимагав особливої активності здійснювався у вигляді розумових навичок. У цьому випадку і матеріал, на який спрямований такий спосіб дій, входив до змісту не цілей, а умов ii досягнення. Складний спосіб дій, що вимагав розумової активності, здійснювався у вигляді самостійної цілеспрямованої дії. У цьому випадку і матеріал, на який він був спрямований, починав займати місце основної мети дії.

Змістовні способи дії виявлялися продуктивнішими у мимовільному запам'ятовуванні, по-перше, тому, що вони відкривали глибші і суттєвіші властивості, зв'язки та відношення у матеріалі порівняно з менш змістовними способами; по-друге, тому що активність, яка вимагалася у цих випадках, сприяла перетворенню цих способів на самостійні цілеспрямовані дії [3].

У розвитку психологічної науки на півдні України неможливо залишити без уваги вченого зі світовим ім'ям - М. М. Ланге. Перша лабораторія експериментальної психології в Росії і в Україні, відокремлена від кафедр психіатрії, фізіології, філософії, була відкрита в Одеському (Новоросійському) університеті в 1896 році. Її засновником і визнаним основоположником вітчизняної експериментальної психології $\mathrm{\epsilon}$ М. М. Ланге. Її створення наперед визначили самостійні експериментальні досліди широко досліджуваних психічних феноменів: уваги і перцепції, які дозволили одержати М.М. Ланге широку світову відомість. Результати дослідів та їх теоретичне обгрунтування М.М. Ланге виклав у докторській дисертації «Психологічні дослідження. Закон перцепції. Теорія вольової уваги» (1893) - першому в Росії і в Україні експериментальному психологічному дослідженні, що набуло визнання класичного. На захисті дисертації, який відбувся у Московському університеті (1894), між М. М. Ланге та його опонентами С. С. Корсаковим i Л.М. Лопатіним розв'язалася дискусія. Велася вона навколо питань, що стосуються правомірності самого експериментального методу в психології. М.М. Ланге виступив за впровадження експериментального методу для дослідження психічних явищ, організаційне оформлення психології в самостійну науку $[10 ; 11 ; 12]$.

Об'єктом психологічних досліджень, на думку М. М. Ланге, повинен стати психічний світ (психосфера), реальність, яку не можна ототожнювати ні зі свідомістю, ні $з$ поведінкою, ні з ментальністю. Психічний світ простягається від нижчих живих організмів до людини й існує за своїми специфічними законами, має свої характерні ознаки, взаємозв'язки з біологічними і соціальними процесами. Одиницею психічного світу є індивідуальне психічне життя. У ньому розгортаються закономір- 
ності психічного світу, що проявляються в різноманітних поведінкових реакціях. Від об'єктивних процесів, що розгортаються в індивідуальному психічному житті, М.М. Ланге відокремлює суб'єктивне переживання цих процесів кожним конкретним індивідом. Для кожного індивіда психічне життя є ланцюжком його суб'єктивних переживань, які безпосередньо виникають у свідомості. Таким чином він розмежовує об'єднане в суб'єкті об'єктивне та суб'єктивне, а згодом і поняття про організм і особистість.

Ідеї М.М. Ланге були підхоплені С. Л. Рубінштейном. Ним було переглянуто основне поняття психології - поняття свідомості, створена теорія психічного як єдиного психофізіологічного процесу, почато фундаментальне експериментальне вивчення мислення. Д. Г. Елькін, теж один із послідовників М. М. Ланге, провів фундаментальні експериментальні дослідження в галузі психології сприймання часу $[10 ; 11 ; 12]$.

Ідеї становлення людської особистості, його джерел та рушійних сил розроблялися С. Л. Рубінштейном, який більшу частину свого життя перебував в Україні, а саме в Одесі. Універсально освічена людина, він відстоював особистісну гідність ученого, пов'язував психологічні проблеми 3 буттєвою долею людини. Великий знавець вітчизняної та світової психології, він насамперед сприяв становленню психології в Україні. Багато його учнів стали відомими науковцями. Рубінштейн, зокрема, висунув неоціненну ідею про логічний осередок побудови системи психологічних знань. Цей осередок, зрештою, має бути архетипом загальнолюдської культури і визначається як дія - вчинок.

Проблема часу стала однієї з перспективних і суперечливих проблем у психології. Д. Г. Елькін розпочинає вивчення цього питання в умовах крайнього загострення протиріч світоглядних поглядів. Свою наукову діяльність Д. Г. Елькін почав у 1922 р. 3 досліджень сприймання часових та просторових відношень у дітей, особливості побудови ними часової перспективи. Перші експериментальні дослідження Д.Г. Елькіна повинні були показати причинну залежність між безпосереднім сприйманням часу і формуванням часової перспективи, основних понять і уявлень про час. У цих дослідження було констатовано, що діти віком від восьми до дванадцяти років, які відтворюють дані тривалості до однієї хвилини найбільш стабільно, мають найбільш широкі уявлення про часові поняття. Але строгої математичної залежності виявлено не було. Він проводить і педологічні дослідження з вимірювання інтеллекту, розумової працездатності, дослідження процесів пам'яті тощо. Результати експериментальних досліджень впливу ритму і темпу на процеси пам'яті та мислення були надруковані у французьких та німецьких психологічних журналах $[10 ; 11]$.

У подальших дослідженнях Д.Г. Елькін звертається до детального дослідження процесу сприймання часу. Експериментальні дослідження, що висвітлюють питання про мозкову локалізацію сприймання тривалості, швидкості, послідовності, ритму, показали, що у сприйманні часу варто розрізняти безпосереднє сприймання часу й опосередковане сприймання часу, що розвивається на його основі. Безпосереднє сприймання часу $є$ простою часовою чутливістю, що локалізується в зоровому бугрі, а опосередковане сприймання часу - складною гностичною функцією 3 кортикальною локалізацією. В цілому процесс сприймання часу Д.Г. Елькін відніс до числа складних аналітико-синтетичних процесів [13].

Під керівництвом Д. Г. Елькіна було проведено ряд досліджень прикладного характеру, які показали, що диференціація часу піддається керуванню. Для цієї мети була розроблена модель диференціації часу як периферичного процесу. На основі цієї моделі були створені корекційні програми, за допомогою яких значно підвищувалася точність тривалості рухових дій, удосконалювалася організація праці при домінуючій ролі зорового, слухового аналізаторів. Подальші дослідження показали, що в основі моделі диференціації часу може бути 
покладений і механізм центрального характеру, а саме - паттерн тривалості в корі великих півкуль головного мозку.

Д. Г. Елькін поширює уявлення про провідну роль інтероцепції у процесі відліку часу на процес диференціації часу, доповнивши його положеннями з теорії установки, розробленої Д. М. Узнадзе: диференціація часу у стані пильнування випробовує на собі виразний вплив установок асимілятивного і контрастного характеру. Ці установки, на його думку, не є результатом свідомого порівняння тривалості інтервалів, а діють як своєрідна спрямованість особистості, що не усвідомлюється. Вона у свою чергу залежить від суб'єктивного переживання плинності часу - швидкої або повільної. Так, він умовно поділяє особистості на дві групи - на тих, для яких час спливає швидко, і тих, для яких він спливає повільно [13].

Суб'єктивне переживання перебігу часу, яке викликає неусвідомлювану спрямованість особистості, є несвідомим компонентом у диференціації часу. Саме це, на думку Д.Г. Елькіна, є джерелом виникнення стійких тимчасових помилок і джерелом зміни в оцінці часу при емоційних станах.

Визначальним у розумінні часу стає час життя - переживання. Психологічний аналіз сприймання часу був викликаний дискусією про кількість основних властивостей відчуттів. Остаточно вчені дійшли висновку, що таких властивостей чотири. Однією з них визначили тривалість. В основі оцінки часу лежить безпосередня тривалість, обумовлена певним фізіологічним механізмом [13].

Проблеми сприймання часу у психології привертали до себе увагу відомих в Україні та за іiі межами вчених: Г. І. Челпанова, І.П. Павлова. Д.Г. Елькін по-новому ставить проблему часу, перевівши іiї з рівня експериментального вивчення в межах відчуттів до експериментального вивчення сприймання, тобто експериментальне вивчення часу було виведене ним за межі тривалості, яка безпосередньо переживається. Під впливом панування в науці радянського періоду ідеології матеріаліз- му Д.Г. Елькін відмовляється від уявлень про природжений механізм сприймання часу, що спричинило спростування факту тривалості, яка безпосередньо переживається, а разом із ним і поняття суб'єктивного часу. Ним послідовно відстоюється матеріалістична точка зору про об'єктивність часу $[11 ; 12]$.

У той же час експериментальні дані, отримані вченим, вступали в суперечність 3 постулатом про об'єктивність часу. Визнавши об'єктивність часу, Д.Г. Елькін пояснював природу виникнення помилок при відтворенні тривалості, спираючись на закономірності, що підтверджують природжений механізм сприймання часу. Таке пояснення $є$ як прямим, так і непрямим доказом існування суб'єктивної міри часу у психіці людини.

Розглянувши сприймання часу як замкнений цикл, Д.Г. Елькін показав, що його моделювання можна вважати за периферичний процес і за процес, пов'язаний зі змінами центрального характеру. Взагалі процес моделювання часу залежить від впливу нервових імпульсів і осциляцій, що характеризують психофізіологічні особливості сенсомоторики, які у свою чергу мають індивідуальні відмінності за типом вищої нервової діяльності, домінування першої або другої сигнальної системи. Він виділяв два рівні моделювання часу у психіці людини: безпосереднє моделювання часу і опосередковане моделювання часу [13].

Для пояснення феномена плинності часу в свідомості людини Д. Г. Елькін спирався на дані хронобіології (Б'юнінг, Ашофф) і теорію установки (Д.М. Узнадзе), власні експериментальні дані. Розроблена ним модель переживання плинності часу складається 3 двох ієрархічних рівнів. Перший рівень, фізіологічна основа, визначається ритмічною активністю органів кровообігу. Другий рівень, спрямованість особистості, що не усвідомлюється, об'єднує два типи особистості: тип особистості зі швидким суб'єктивним переживанням часу i тип особистості з повільним суб' єктивним переживанням часу [13]. 
Експериментальні дослідження, проведені самим Д.Г. Елькіним та під його керівництвом, оформилися в цілісну наукову програму під назвою «Психологія диференціації часу».

Висновки. Таким чином, можна підсумувати, що розвиток психологічних вчень відбувався виключно в наукових осередках як колективна творчість групи вчених, очолюваних своїми лідерами. У Харкові на початку лідерами виступали Л.С. Виготсь- кий та О.М. Леонтьєв, що власне створили харківську групу вчених, а вже в середині XX століття науковим лідером виступав П.І. Зінченко. В одеському науковому осередку вчення грунтувались на ідеях M. М. Ланге, що мали початок ще у XIX століття, але залишаються цінними і до теперішнього часу. Ідеї М. М. Ланге були підхоплені С. Л. Рубінштейном та Д. Г. Елькіним й розвиваються та використовуються у сучасних психологічних дослідженнях.

\section{Список використаних джерел:}

1. Зинченко П. И. Проблема непроизвольного запоминания / П. И. Зинченко // Научн. записки Харьковского пед. инта ин. яз. - Харьков : Изд-во ХГПИИЯ, 1939. — Т. 1. — С. 145 187.

2. Зинченко П. И. О забывании и воспроизведении школьных знаний / П. И. Зинченко // Научн. записки Харьковского пед. ин-та ин. яз. — Харьков : Изд-во ХГПИИЯ, 1939. — Т. 1. - C. 189-213.

3. Зинченко П.И. Вопросы психологии памяти / П.И. Зинченко // Психологическая наука в СССР. - М. : АПН РСФСР, 1959. - Ч. 1. - С. 221-256.

4. Зинченко П.И. Вопросы развития процессов запоминания / П. И. Зинченко // Вопр. психол. - 1960. - №6. - С. 75-81.

5. Зинченко П.И. Непроизвольное запоминание / П.И. Зинченко. - М. : Изд-во АПН РСФСР, 1961. - $562 \mathrm{c}$.

6. Зинченко П.И. Исследования психологии памяти / П.И. Зинченко // Проблемы психологии памяти. - Харьков : Изд-во ХГУ, 1969. - С. 3-11.

7. Зинченко П. И. Исследования по психологии памяти и обучения / П. И. Зинченко // Вестн. Харьк. ун-та. - 1968. - Вып. 1. - №30. - (Проблемы психологии памяти и обучения).

8. Лактионов А.Н. История харковской психологической школы / А. Н. Лактионов // Вестн. Харьк. ун-та. - 1989. - №337. Психологія особистості і пізнавальних процесів. C. $19-22$.

9. Лактионов А.Н. Деятельностная парадигма и проблема памяти в трудах П.И. Зинченко (к 90-летию со дня рождения) / А.Н. Лактионов, Г.К. Середа // Вопр. психол. - 1993. — №4. - C. 102-108.

10. Пивоварчик I.M. Історія становлення психологічних наукових шкіл на півдні України (XIX-XX ст.) : дис. ... канд. психол. наук : 19.00.01 / Ірина Михайлівна Пивоварчик / Південноукраїнський держ. педагогічний ун-т ім. К. Д. Ушинського. — О., 2006. — 296 арк. : іл.+ дод. - Бібліогр. : арк. 185-218.

11. Указная Л.Н. Психоневрологические исследования Д. Г. Элькиным восприятия времени / Л.Н. Указная // Матеріали других Міжнародних психологічних читань «Актуальні проблеми сучасної психології» // Методологічні та теоретичні проблеми психології. — Харків, 1995. - С. 24.

12. Указна Л.Н. Д. Г. Елькін - видатний дослідник психології сприймання часу / Л.Н. Указна, Б. Й. Цуканов // Педагогіка і психологія. — 1995. — № 4. - С. 176-178.

13. Элькин Д. Г. Восприятие времени / Д. Г. Элькин. - М. : АПН РСФСР, 1962. - 311 с.

14. Ясницкий А. Очерк истории Харьковской школы психологии: первая научная сессия Харьковского государственного педагогического института и появление «Харьковской школы психологии» (1938) / А. Ясницкий // Культурно-историческая психология. — № 2. - 2009. - C. 95-106.

Аннотация. В статье проанализированы психологические исследования в Украине, что проходили на основе экспериментальных данных и идей ведущих научных лидеров, которые внедряли свои теоретико-методологические положения с помощью своих друзей и соратников. Таким образом, образовывались творческие группы, которые совместно работали и поддержсивали друг друга в научных исследованиях. Наиболее известныли, кроме киевской группы, стали творческие 
коллективы, образовавшиеся в Харькове и Одессе. Их основные исследования освещуали такие темы: проблемы непроизвольной и произвольной памяти, особенности продуктивного запоминания, экспериментальное изучение проиесса мышления, исследования восприятия времени.

Ключевые слова: украинская психология, сознание, память, восприятие времени.

Abstracts. The development of Ukrainian psychology took place in difficult social circumstances in which science was hostage to political as well as economic factors. Ukrainian state as a political institution, did not exist, and therefore there was no single community center, which would be a source of development of psychology in Ukraine.

Ukrainian Psychological research was based on ideas of well known scientists and their experiments, they have implemented their theories and methods with the help of their friends and associates. That is how creative groups were developed. They have helped and supported each other research developments. The most famous were groups from Kiev, Kharkov and Odessa. Their main research topics included problems of involuntary and voluntary memory, basics of productive memorization, experimental study of a thinking process and a study of perception of time.

The development of psychological theories took place exclusively in the research centers as a collective work of a group of scientists headed by its leaders. In Kharkov, in the early leaders were L.S. Vygotsky and A. N. Leontiev, that actually created the Kharkov group of scientists, and in the mid-twentieth century scientific leader spoke P. I. Zinchenko. In Odessa scientific doctrine were based on the ideas of M. M. Lange, which extended in the nineteenth century, but remain valuable and up to date. The ideas of M.M. Lange were picked up by S. L. Rubinstein and D. G. Elkin which are developing and used in modern psychological research.

Keywords: Ukrainian psychology, consciousness, memory, perception of time. 